\title{
THE IRISH FOREST SOILS PROJECT AND ITS POTENTIAL CONTRIBUTION TO THE ASSESSMENT OF BIODIVERSITY
}

\author{
M. Loftus, M. Bulfin, N. Farrelly, R. Fealy, S. Green, R. Meehan \\ and T. Radford
}

\begin{abstract}
The United Nations Environment Programme (UNEP) has proposed methods and thematic areas for data collection that are appropriate to the evaluation of biodiversity. The Heritage Council has identified a paucity of data on habitats in Ireland. Within this context, we outline the Irish Forest Soils (IFS) element of the Forest Inventory and Planning System (FIPS) and present a detailed account of land-cover mapping, which is an important aspect of the project. The IFS project aims to produce a national thematic map of land cover using soft-copy photogrammetry, combined with satellite-image classification and field survey. This aspect of the IFS project generates data on land cover at different spatial and classification resolutions. We report on the progress made to date and present illustrative examples of the data sets. The UNEP proposals provide a useful framework within which to discuss the potential contribution of IFS data to the assessment of biodiversity.
\end{abstract}

M. Loftus

(corresponding author; e-mail:mloftus@ kinsealy.teagasc.ie), M. Bulfin, N. Farrelly, R.

Fealy, S. Green, R.

Meehan and $\mathrm{T}$.

Radford, Teagasc,

Kinsealy Research

Centre, Malahide Road,

Dublin 17, Republic of

Ireland.

\section{BIODIVERSITY: BACKGROUND AND CONTEXT}

'Biodiversity' is a term used to describe biological diversity at three hierarchically related levels of biological organisation, i.e. genetic, species and ecosystem diversity (McNeely 1988). The United Nations Environment Programme published a report following a meeting on the development of indicators of biological diversity (UNEP 2000). The meeting resulted in the proposal of a core set of state biodiversity indicators relating to ecosystem quantity and quality in the following thematic areas: forest biodiversity, marine and coastal biodiversity, inland water biodiversity, dryland biodiversity, mountain biodiversity and agrobiodiversity. Types of data sets and methods of quantifying and qualifying biodiversity indicators were proposed (Table 1). These proposals will act as a useful framework within which to consider the potential contribution that the data sets generated within the Irish Forest Soils element of the Forest Inventory Planning System (FIPS-IFS) will make to the assessment of biodiversity in Ireland. Given the paucity of information in Ireland on ecosystem diversity, the data generated within FIPS-IFS will contribute to this body of baseline information.

THE FOREST INVENTORY AND

PLANNING SYSTEM AND THE IRISH

FOREST SOILS PROJECT (FIPS-IFS)

FIPS and IFS are the result of strategic actions designed to implement forestry policy on inventory and planning as outlined in a strategic plan for the development of the forestry sector in Ireland (Department of Agriculture, Food and Forestry 1996). The stated policy is 'to develop a comprehensive inventory and planning system to provide forest resource, geographical and environmental data for management, control and planning purposes'. The three main elements of FIPS arising from the strategic actions include (i) a forest inventory and classification project, (ii) a forest grant and premium administration system and (iii) a forest soils classification project. This final element is called the Irish Forest Soils project, or FIPS-IFS, and it envisages the mapping of broad soil categories to a detailed reconnaissance level throughout the Republic of Ireland. A detailed reconnaissance soil survey in Ireland is currently incomplete (Coulter et al. 1996) (Fig. 1). The objectives of FIPS-IFS (Bulfin 1998) are (i) to develop a national digital soils classification and a soil productivity ranking based on forestry potential and (ii) to provide the necessary soils information to the Indicative Forest Strategy, used by the Forest Service in guiding the location and character of new afforestation at county, regional and national level. Although not originally envisaged (Bulfin 1998), the production of the necessary soils information for the Indicative Forestry Strategy generated data relevant to the assessment of biodiversity. 
Table 1-Proposed core set of biodiversity indicators (from UNEP 2000).

\begin{tabular}{|c|c|c|c|c|c|c|c|c|c|c|c|}
\hline \multirow{2}{*}{$\begin{array}{l}\text { State } \\
\text { indicator }\end{array}$} & & & \multicolumn{6}{|c|}{ Thematic areas } & \multirow[t]{2}{*}{ Data sets } & \multirow[t]{2}{*}{ Methods } & \multirow[t]{2}{*}{ Comments } \\
\hline & & & $F$ & $M / C$ & $I W$ & $D$ & $M$ & $A g$ & & & \\
\hline $\begin{array}{l}\text { Ecosystem } \\
\text { quantity }\end{array}$ & $\begin{array}{l}1.0 \\
1.1 \\
1.2\end{array}$ & $\begin{array}{l}\text { Habitat } \\
\text { Self-regenerating } \\
\text { Man-made }\end{array}$ & $\star \star$ & $\star$ & $\begin{array}{l}\star \\
\star\end{array}$ & $\begin{array}{l}\star \\
\star\end{array}$ & $\begin{array}{l}\star \\
\star\end{array}$ & $\star$ & $\begin{array}{l}\text { Remote sensing data, } \\
\text { vegetation maps, } \\
\text { forest-cover } \\
\text { inventories, coastal } \\
\text { zone maps, wetland } \\
\text { and freshwater } \\
\text { inventories }\end{array}$ & $\begin{array}{l}\text { Overlay maps, GIS, } \\
\text { aerial surveys, ground } \\
\text { truthing }\end{array}$ & $\begin{array}{l}\text { Measured as } \% \text { area/total } \\
\text { land. Shows the extent } \\
\text { of the area and whether } \\
\text { habitat is being gained } \\
\text { or lost in recent times }\end{array}$ \\
\hline \multirow{17}{*}{$\begin{array}{l}\text { Ecosystem } \\
\text { quality }\end{array}$} & & Ecosystem & & & & & & & & & \\
\hline & 2.0 & $\begin{array}{l}\text { Habitat } \\
\text { fragmentation } \\
\text { /conversion }\end{array}$ & & & & & & & $\begin{array}{l}\text { Land-use plans, } \\
\text { remote sensing data, } \\
\text { surveys, FAO data }\end{array}$ & GIS, overlay maps & $\begin{array}{l}\text { Shows trends in } \\
\text { significant habitat } \\
\text { disturbance }\end{array}$ \\
\hline & 2.1 & $\begin{array}{l}\text { Native vegetation } \\
\text { fragmentation }\end{array}$ & $\star$ & $\star$ & $\star$ & $\star$ & $\star$ & & & & \\
\hline & 2.2 & $\begin{array}{l}\text { Wetland drainage } \\
\text { and filling }\end{array}$ & $\star$ & $\star$ & $\star$ & $\star$ & & & & & \\
\hline & 2.3 & $\begin{array}{l}\text { Conversion of } \\
\text { coastal areas }\end{array}$ & & $\star$ & $\star$ & & & & & & \\
\hline & 2.4 & Erosion & $\star$ & $\star$ & $\star$ & $\star$ & $\star$ & $\star$ & & & \\
\hline & 2.5 & Irrigation & & & & $\star$ & & $\star$ & & & \\
\hline & 3.0 & Species richness & $\star$ & $\star$ & $\star$ & $\star$ & $\star$ & $\star$ & $\begin{array}{l}\text { National biodiversity } \\
\text { database, surveys, } \\
\text { transect, sampling } \\
\text { reports }\end{array}$ & $\begin{array}{l}\text { Monitoring and } \\
\text { research programs, } \\
\text { inventories }\end{array}$ & $\begin{array}{l}\text { Species richness data are } \\
\text { being collected widely } \\
\text { (at different taxonomic } \\
\text { levels), but their use as } \\
\text { an indicator is limited } \\
\text { by uncertainty regarding } \\
\text { the total number of } \\
\text { species present and by } \\
\text { taxonomical difficulties }\end{array}$ \\
\hline & & Species & & & & & & & & & \\
\hline & 4.0 & $\begin{array}{l}\text { Change in } \\
\text { abundance and/or } \\
\text { distribution of a } \\
\text { selected core of } \\
\text { species }\end{array}$ & $\star$ & $\star$ & $\star$ & $\star$ & $\star$ & $\star$ & $\begin{array}{l}\text { Wide area, transect, } \\
\text { sample results }\end{array}$ & $\begin{array}{l}\text { Surveys and } \\
\text { monitoring programs, } \\
\text { depending on the } \\
\text { species involved }\end{array}$ & $\begin{array}{l}\text { Provides information on } \\
\text { ecological changes and } \\
\text { ecosystem processes. } \\
\text { Species in the set to be } \\
\text { included on the basis of } \\
\text { country-specific } \\
\text { conditions (e.g. rare, } \\
\text { endemic, keystone, } \\
\text { flagship, economic, etc.) }\end{array}$ \\
\hline & 5.0 & Threatened species & & & & & & & Endangered and & Surveys and & Indicates species for \\
\hline & 5.1 & $\begin{array}{l}\text { Threatened species } \\
\text { as } \% \text { of total } \\
\text { species or certain } \\
\text { taxonomic groups }\end{array}$ & $\star$ & $\star$ & $\star$ & $\star$ & $\star$ & $\star$ & $\begin{array}{l}\text { threatened species } \\
\text { data sets }\end{array}$ & monitoring & $\begin{array}{l}\text { which most urgent } \\
\text { actions are needed }\end{array}$ \\
\hline & 5.2 & $\begin{array}{l}\% \text { Endemic species } \\
\text { threatened }\end{array}$ & $\star$ & $\star$ & $\star$ & $\star$ & $\star$ & $\star$ & & & \\
\hline & 5.3 & $\begin{array}{l}\text { Threatened species } \\
\text { in protected areas }\end{array}$ & $\star$ & $\star$ & $\star$ & $\star$ & $\star$ & $\star$ & & & \\
\hline & & Genetics & & & & & & & & & \\
\hline & 6.0 & $\begin{array}{l}\text { Replacement of } \\
\text { indigenous crops }\end{array}$ & $\star$ & & $\star$ & $\star$ & $\star$ & $\star$ & $\begin{array}{l}\text { Allelic diversity, } \\
\text { karyotype variants }\end{array}$ & $\begin{array}{l}\text { Morphological } \\
\text { analysis, offspring }\end{array}$ & $\begin{array}{l}\text { Will provide } \\
\text { information on }\end{array}$ \\
\hline & 6.1 & $\begin{array}{l}\text { Replacement of } \\
\text { land races with } \\
\text { few imported ones }\end{array}$ & & & $\star$ & $\star$ & $\star$ & $\star$ & & $\begin{array}{l}\text { parent regression, } \\
\text { DNA sequencing, } \\
\text { electrophoresis, } \\
\text { karyotypic analysis }\end{array}$ & $\begin{array}{l}\text { inbreeding depression, } \\
\text { outbreeding rate, rate of } \\
\text { genetic drift, genetic } \\
\text { flow, etc. }\end{array}$ \\
\hline
\end{tabular}

$\mathrm{F}=$ forest biodiversity; $\mathrm{M} / \mathrm{C}=$ marine and coastal biodiversity; $\mathrm{IW}=$ inland water biodiversity; $\mathrm{D}=$ dryland biodiversity; $\mathrm{M}=$ mountain biodiversity; $\mathrm{Ag}=$ agrobiodiversity. 


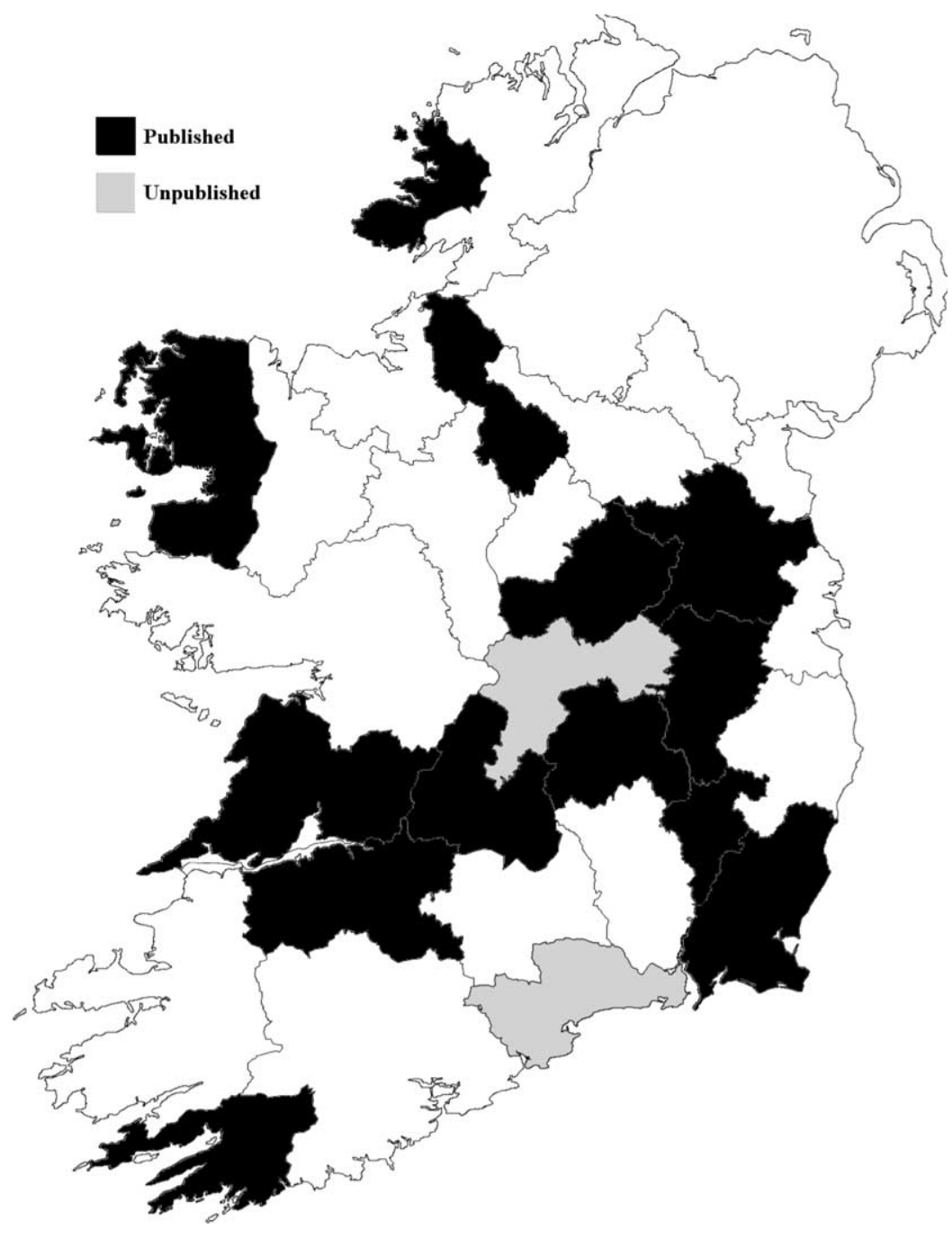

Fig. 1-Detailed reconnaissance soil survey in Ireland.

\section{MATERIALS AND METHODS IN FIPS-IFS}

Within the Irish Forest Soils classification project, a number of themes are mapped nationally by means of remotely sensed imagery and ancillary data, from which soil type, productivity and distribution are modelled. These themes include parent materials, topography and land cover. The association of themes with soil type is modelled by means of thematic maps and field data within a geographic information system (GIS). The soil types modelled fall into five broad classes: shallow mineral well drained; deep mineral well drained; mineral poorly drained; peat over mineral; and peat. Finally, forest productivity rankings will be ascribed to different soil types on the basis of analysis of existing forest productivity data sets and supplementary fieldwork.

Parent materials are mapped by means of soft-copy photogrammetric software (ATLAS) and digital stereo pairs of black-and-white aerial photographs taken in 1995 (scale 1:40,000), as well as fieldwork. Various categories of till, peat, sand and gravel, alluvial, aeolian, estuarine and lacustrine deposits, as well as bedrock outcrop, are classified and mapped. Topographic analysis is being undertaken using a digital elevation model (DEM) derived from the same aerial photographs with ArcView 3.1. The topographic analysis describes different altitude, aspect, slope and slope-curvature classes. Land cover is mapped by means of soft-copy photogrammetry combined with satellite-image classification, as well as fieldwork. The utility of land-cover mapping for the IFS project lies in the fact that land-cover classes can be used as an aid to soil modelling. This mapping aspect of the project forms the basis for biodiversity assessment, which is the focus of the rest of this paper.

\section{LAND-COVER MAPPING}

The aim of land-cover mapping in the FIPS-IFS project is to aid in the identification and mapping of free and poorly drained mineral soils throughout the country. A land-cover map is being produced with a combination of aerial photography and satellite imagery. The focus of this exercise is to exploit the known ecology of grassland types in Ireland in relation to soils (O'Sullivan 1982). There are three main elements to land-cover mapping in FIPS-IFS: training data, supervised classification of satellite imagery and field surveys. Although each approach is associated with different spatial and classification resolutions, each produces data that could be used in assessing biodiversity in Ireland.

\section{Training data}

The production of a nationwide land-cover map with minimum mapping units ranging from tha to 5ha from aerial photographs alone could not be achieved within the timescale of the FIPS-IFS project. We therefore decided to use a procedure involving both satellite imagery and aerial photographs to produce a national land-cover map.

In the context of satellite-image analysis, training data, which represent samples whose identity is known, are used to classify unknown areas in the image. Training data are a key element in the supervised classification of satellite imagery (Campbell 1996). They should typify the spectral properties of whichever category they represent, in this case categories of land cover. Training data can be collected in the field or from remotely sensed imagery of higher resolution than the imagery being classified. The resolution of the aerial photographs used in the FIPS-IFS project is $1 \mathrm{~m}^{2}$, whereas the resolution of the Landsat thematic 
mapper (TM) imagery is $25 \mathrm{~m}^{2}$. The finer spatial resolution of the aerial photographs allows for greater discrimination of land cover and justifies their use in the collection of training data for the satellite imagery.

Aerial photographs have been widely used in mapping elements of land cover, including a survey of neglected agricultural land in the Sperrin Mountains, Northern Ireland (Cruickshank and Cruickshank 1977), a peatland inventory for Northern Ireland (Tomlinson 1984; Cruickshank and Tomlinson 1990) and a stratification of the Wicklow Mountains for a botanical field-sampling strategy (Loftus 1994; Cooper and Loftus 1998). They have also been used to identify and illustrate the distribution patterns of woodlands and hedgerows in contrasting landscapes (Loftus et al. 1998). These studies successfully illustrated the distribution of land-cover elements; however, they focused mostly on particular land-cover types or were restricted to limited geographical areas. The FIPS-IFS project is unique in an Irish context in the way it uses black-and-white aerial photographs and satellite imagery to produce a national thematic map of land cover.

The collection of training data on land cover is central to the supervised classification of Landsat TM imagery. Apart from recent technological advances in soft-copy photogrammetry, the use of aerial photographs in land-cover mapping follows established standard procedures (Howard 1970; Baker et al. 1979; Campbell 1983). Within the FIPS-IFS project, training data are collected by means of soft-copy photogrammetry, which facilitates digital data capture. Black-and-white aerial photographs (scale 1:40,000) from 1995 have been scanned to create digital copies. Using accurate positional information recorded from global positioning systems (GPS) and data from the aircraft's navigational system that record the orientations of the photograph, photogrammetric software reconstructs the geometry of the image, rendering the positional accuracy at $5-10 \mathrm{~m}$ (rms). The digital images are used as input for a series of models that permit three-dimensional, planimetrically correct viewing of the landscape and allow training data to be gathered. The training data are gathered from an area circumscribed by a radius of $50 \mathrm{~m}$ from the training point. The minimum mapping unit could therefore be described as $0.78 \mathrm{ha}$. The training data follow a land-cover classification designed according to a national standard (Fossitt 2000). The classification (Table 2) is adjusted to cater for the aims of the FIPS-IFS project in defining free and well-drained soils and to allow for the limitations of supervised classification.

The sample mapping procedure has evolved over the course of the FIPS-IFS project. In Mayo, the first county to be mapped, the strategy was to map the bottom left-hand $1 \mathrm{~km}$ grid square from every $100 \mathrm{~km}$ grid square. This sampling strategy had previously been adopted in the badger and habitat survey of Ireland (Smal 1995). The Mayo survey was conducted in the field, and the resulting maps were used in aerial photograph interpretation. In County Cork and part of County Donegal, we adopted a different sampling strategy and classified every point at the intersection of northings and eastings at $1 \mathrm{~km}$ intervals. Following this, in the remainder of Donegal and in subsequent counties (Roscommon, Sligo, Waterford, Limerick, Kerry, Galway, Leitrim, Monaghan, Louth and Longford), we classified the intersection of northings and eastings at $2 \mathrm{~km}$ intervals. The output data that were generated were easily integrated into geographic information systems and remote sensing software.

\section{Supervised classification of satellite imagery}

Landsat TM imagery has been used to produce land-cover maps throughout Ireland. The CORINE project provides data on the areal extent of land cover, the data being derived from the classification of cover by visual interpretation of hard copies (scale 1:100,000) of Landsat TM images of May 1990 (O’Sullivan 1994). Among the conclusions of this work was that interpretation varies among different interpreters (Cruickshank and Tomlinson 1996).

Supervised classification is the process of using samples of known identity (training areas, i.e. pixels assigned to classes) to classify pixels of unknown identity (i.e. to assign unclassified pixels to classes). The analyst defines training areas by identifying regions on the image that can be clearly matched to areas of known identity from contemporary aerial photographs or other ancillary data. Such areas should typify spectral properties of the categories they represent and, of course, should be homogeneous in respect of the information category to be classified.

Within the FIPS-IFS project, training data are used to produce a supervised classification of satellite imagery collected by the TM sensor on board Landsat 5. The imagery was chosen to be contemporary with the aerial photography (1995). The resolution of the imagery is $30 \mathrm{~m}$, resampled to $25 \mathrm{~m}$. The positional accuracy of the imagery is quoted as approximately one and a half times that of the resolution of the imagery, or approximately $40 \mathrm{~m}$ (RMS). The minimum mapping unit, yet to be finally determined, will be between 1 ha and 5 ha.

The resulting thematic map of land cover illustrates the distribution of thematic classes of land cover and represents groupings of vegetation 
Table 2-Vegetation codes used in training data collection exercise.

\begin{tabular}{|c|c|c|c|c|}
\hline No. & Level 1 & Level 2 & Level 3 & Code \\
\hline 1 & Not applicable & & & NA \\
\hline 2 & & Salt marsh & Salt marsh & CM1 \\
\hline 3 & & Sand dune system & Foredune & CD1 \\
\hline 4 & & & Fixed dune & CD2 \\
\hline 5 & & & Dune heath and scrub & CD3 \\
\hline 8 & Freshwater & Lakes and ponds & Turloughs & FL7 \\
\hline 9 & & Swamps & Reedbeds & FS1 \\
\hline 10 & Grassland & Improved grassland & Improved grassland & GI1 \\
\hline 11 & & & Improved grassland, peaty & GI2 \\
\hline 12 & & & Amenity grassland & GI3 \\
\hline 17 & & & Upland dry $0-25 \%$ scrub & GS5 \\
\hline 18 & & & Upland dry $26-50 \%$ scrub & GS6 \\
\hline 19 & & & Lowland wet $10-30 \%$ rush & GS7 \\
\hline 20 & & & Lowland wet $31-50 \%$ rush & GS8 \\
\hline 21 & & & Lowland wet $51-100 \%$ rush & GS9 \\
\hline 22 & & & Lowland wet $0-25 \%$ scrub & GS10 \\
\hline 23 & & & Lowland wet $26-50 \%$ scrub & GS11 \\
\hline 24 & & & Upland wet $10-30 \%$ rush & GS12 \\
\hline 25 & & & Upland wet $31-50 \%$ rush & GS13 \\
\hline 26 & & & Upland wet $51-100 \%$ rush & GS14 \\
\hline 27 & & & Upland wet $0-25 \%$ scrub & GS15 \\
\hline 35 & & & With scattered scrub $26-50 \%$ & $\mathrm{HH} 3$ \\
\hline 36 & & & Wet heath & $\mathrm{HH} 4$ \\
\hline 37 & & & With scattered scrub 5-25\% & $\mathrm{HH} 5$ \\
\hline 38 & & & With scattered scrub $26-50 \%$ & HH6 \\
\hline 39 & & & Montane heath & $\mathrm{HH7}$ \\
\hline 40 & & & With scattered scrub 5-25\% & HH8 \\
\hline 41 & & & With scattered scrub $26-50 \%$ & HН9 \\
\hline 42 & Fern & Fern & Dense bracken & HF1 \\
\hline 43 & Bog & Bog & Lowland blanket bog smooth & BB1 \\
\hline 44 & & & Lowland blanket bog & BB2 \\
\hline 45 & & & With scattered scrub 5-25\% & BB3 \\
\hline 46 & & & With scattered scrub $26-50 \%$ & $\mathrm{BB} 4$ \\
\hline 47 & & & Eroding lowland blanket bog $<25 \%$ & BB5 \\
\hline 48 & & & Eroding lowland blanket bog $<50 \%$ & BB6 \\
\hline 49 & & & Upland blanket bog smooth & BB7 \\
\hline 50 & & & Upland blanket bog & BB8 \\
\hline 51 & & & With scattered scrub $5-25 \%$ & BB9 \\
\hline 52 & & & With scattered scrub $26-50 \%$ & $\mathrm{BB} 10$ \\
\hline 53 & & & Eroding upland blanket bog $<25 \%$ & BB11 \\
\hline 54 & & & Eroding upland blanket bog $<50 \%$ & $\mathrm{BB} 12$ \\
\hline
\end{tabular}


Table 2-(Continued).

\begin{tabular}{|c|c|c|c|c|}
\hline No. & Level 1 & Level 2 & Level 3 & Code \\
\hline 55 & & & Raised bog smooth & BB13 \\
\hline 56 & & & Raised bog & BB14 \\
\hline 58 & & & With scattered scrub $26-50 \%$ & BB16 \\
\hline 59 & & & Eroding raised bog $<25 \%$ & $\mathrm{BB} 17$ \\
\hline 60 & & & Eroding raised bog $<50 \%$ & BB18 \\
\hline 62 & & & Cutover bog traditional & BB20 \\
\hline 63 & & & Cutover bog machine profile & BB21 \\
\hline 64 & & & Cutover bog machine plan & BB22 \\
\hline 65 & & & Cutaway & BB23 \\
\hline 66 & & & Abandoned & BB24 \\
\hline 67 & & & Bare peat & BB25 \\
\hline 72 & & & Native bog woodland & WN5 \\
\hline 73 & & Other woodland & Mixed broadleaved woodland & WO1 \\
\hline 74 & & & Mixed broadleaved/conifer woodland & WO2 \\
\hline 75 & & & Mixed conifer woodland & WO3 \\
\hline 76 & & & Conifer plantation & WO4 \\
\hline 77 & & & Recently planted & WO5 \\
\hline 78 & & & Recently felled & WO6 \\
\hline 79 & & & Recently prepared for planting & WO7 \\
\hline 80 & & & Windthrow & W08 \\
\hline 81 & Scrub & Scrub & Native scrub & WS1 \\
\hline 82 & & & Ornamental/non-native shrub & WS3 \\
\hline 90 & & & Recently cleared/reclaimed & ED6 \\
\hline 91 & Cultivation and built land & Cultivated ground & Arable crops & VC1 \\
\hline 92 & & & Horticultural land & VC2 \\
\hline 93 & & & Ploughed fields & VC3 \\
\hline 94 & & & Flower beds and borders & VC4 \\
\hline 95 & & Built land & Built land & VB1 \\
\hline 96 & Complex & Rock outcropping & Ro grassland & CR1 \\
\hline 97 & & & Ro grassland dry heath & CR2 \\
\hline 98 & & & Ro grassland wet heath & CR3 \\
\hline 99 & & & Ro wet heath & CR4 \\
\hline 100 & & & Ro scrub & CR 5 \\
\hline 101 & & Heath & Wet heath/dry heath & $\mathrm{CH} 1$ \\
\hline 102 & & Wetland & Wetland & CW1 \\
\hline 103 & Miscellaneous & & Border & Border \\
\hline 104 & & & Unsure & Unsure \\
\hline 105 & & & Built land (building and curtilage) & Vb1 \\
\hline 106 & & & Unclassified woodlands & Wn2 \\
\hline 107 & & & Grassland dry heath & Ch2 \\
\hline 108 & & & Grassland wet heath & Ch3 \\
\hline
\end{tabular}

Level 3 codes in most common usage are indicated with bold text. 
classes from the image training data; they are therefore indicative of vegetation type in a broad sense only. The thematic classes are named as follows: dry grasslands; wet grasslands; bog and heath; rock complex; exposed peat; plantation and woodland; scrub and unclosed forestry; built land; and water.

\section{Field survey}

Within the FIPS-IFS project, we have collected field data to validate the various thematic data sets - parent materials, land cover and topography — created by means of remote sensing. The other aim of field surveys is to gather information on the relationship between these thematic areas and soil type. We chose a GPS for field surveys: this is a data collection and management system that records information attributed to a point with a submetre $(50 \mathrm{~cm}$ (RMS)) positional accuracy. The GPS allows for the design of databases, known as data dictionaries, for data collection in the field. Different data dictionaries have been designed for each theme, while simultaneously retaining a core of common attributes. This ensures consistency in data collection in given fields of data from field recorders of different disciplines.

It is important to describe the thematic classes more fully and to explore association with soil type. We do this using field-based data in accordance with the Guide to habitats in Ireland (Fossitt 2000), with some alterations to meet the requirements of the FIPS-IFS project. Table 3 summarises the main attributes of the land-cover data dictionary.

The sampling strategy for fieldwork was guided by the need to acquire field data for the purpose of soil modelling. Soil modelling is particularly difficult in low-elevation grasslands on till; therefore, we gave priority to certain parent materials, elevation ranges and land-cover types for purposes of field survey. We drafted the following guiding principles:

- Areas mapped as water, no data, made ground, estuarine deposits or aeolian deposits during the parent-materials mapping exercise were not a priority for field survey.

- Parent materials mapped as karstified rock outcrop, blanket peat and eskers were a priority for field survey, as these parent materials give rise to very specific soil types, for which no further modelling is needed.

- Parent materials representing 3\% or less of the land area of a county were not given high priority for field sampling. Acidic sands and gravels, alluvials, basic sands and gravels, lacustrine deposits, and sands fall into this category. This was to ensure that scarce time

Table 3-Essential elements of data spreadsheet for field survey of land cover.

Land cover

\footnotetext{
Coastal

Freshwater

Grassland

Salt marsh; foredune; fixed dune; dune heath and scrub; dune slack; machair

Turlough; reedbed

Heath and fern

Amenity grassland; improved grassland; improved grassland on peat; lowland dry grassland; upland dry grassland; lowland wet grassland; upland wet grassland; coarse grassland; marsh

Bog, fen and flush

Dry heath; wet heath; montane heath; dense bracken

Lowland blanket bog; upland blanket bog; raised bog; transition bog; cutover bog; bare peat; fen; flush and spring

Woodland and scrub Oak birch holly wood; oak ash hazel wood; yew woodland; wetland woodland; bog woodland; mixed broad woodland; mixed broadleaved conifer woodland; mixed conifer woodland; conifer woodland; native scrub; ornamental shrub

Complex Complex grass and rock; complex grass dry heath and rock; complex grass wet heath and rock; complex wet heath and rock; complex scrub and rock; complex wet and dry heath; complex wetland

Miscellaneous

Exposed bedrock; exposed scree or loose rock; exposed sand, gravel or till; bare ground/spoil; recolonised bare ground; refuse and other waste; active quarries; recently reclaimed; arable crops; horticultural land; ploughed fields; flower beds/borders; built land

Grasslands Grazing; silage; hay; sward height

Grazers

Cover (\%)

Cattle; sheep; horse; goats; mixed

Poached; bare earth; rush; fern; dock; thistle; scrub (and species)

Bog $(\%)$

Erosion, subparallel; erosion, anastamosing; cutting, hand; cutting, machine

Dominant species
} 


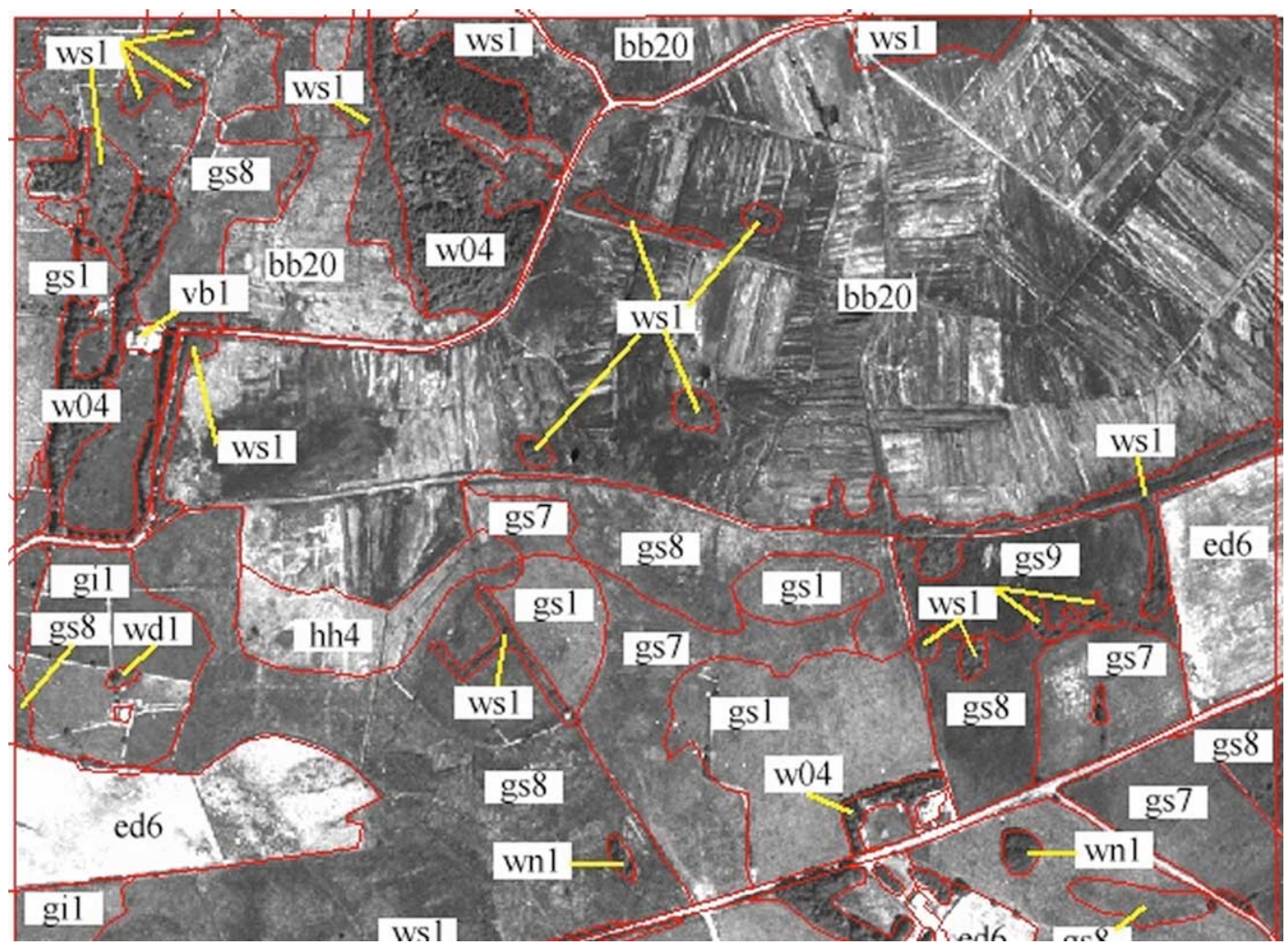

Fig. 2-Example of photogrammetric mapping from a $1 \mathrm{~km}$ grid square of County Mayo. See Table 2 for key to habitat coding.

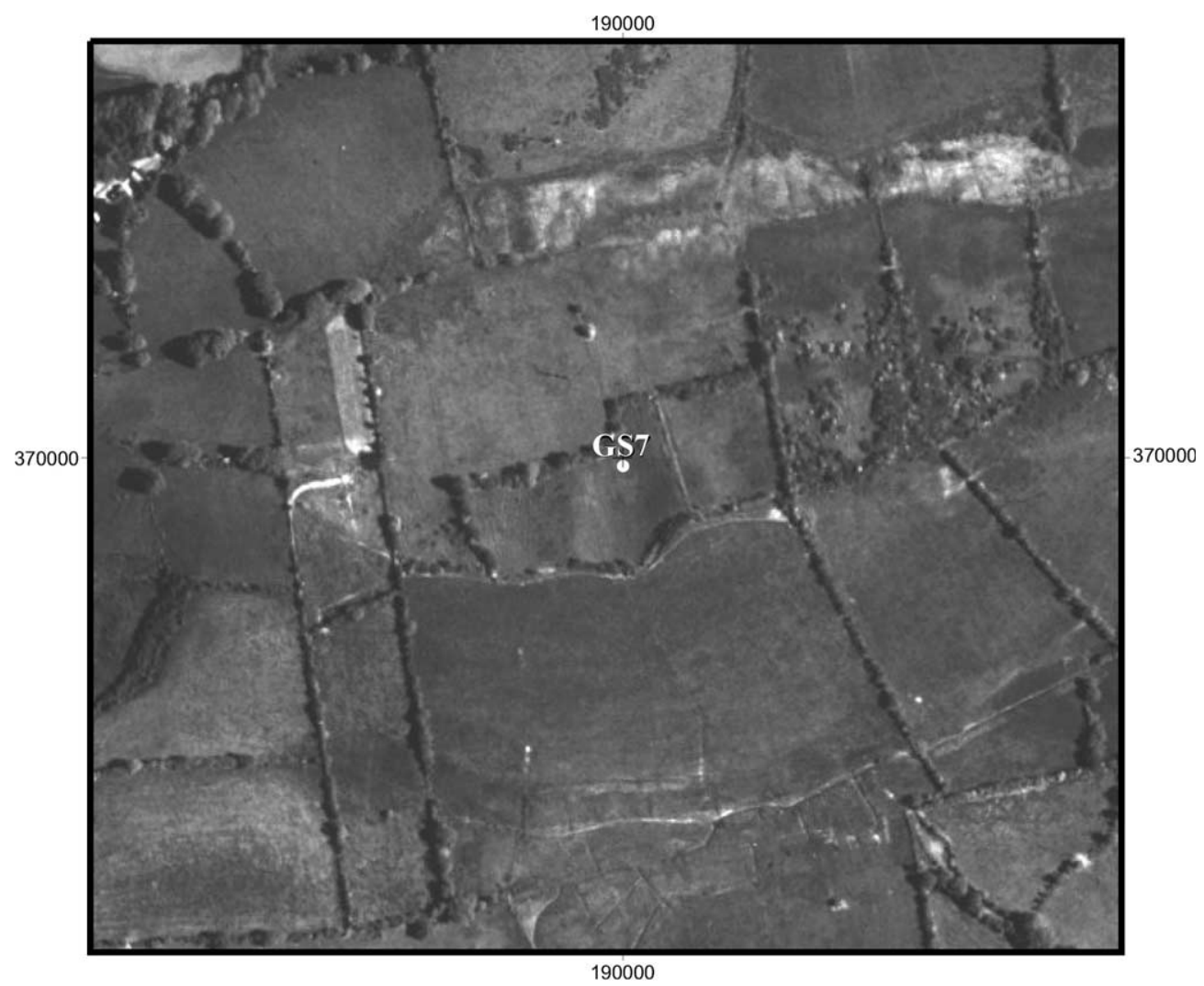

Fig. 3-Example of lowland wet-grassland training data point from County Donegal. 


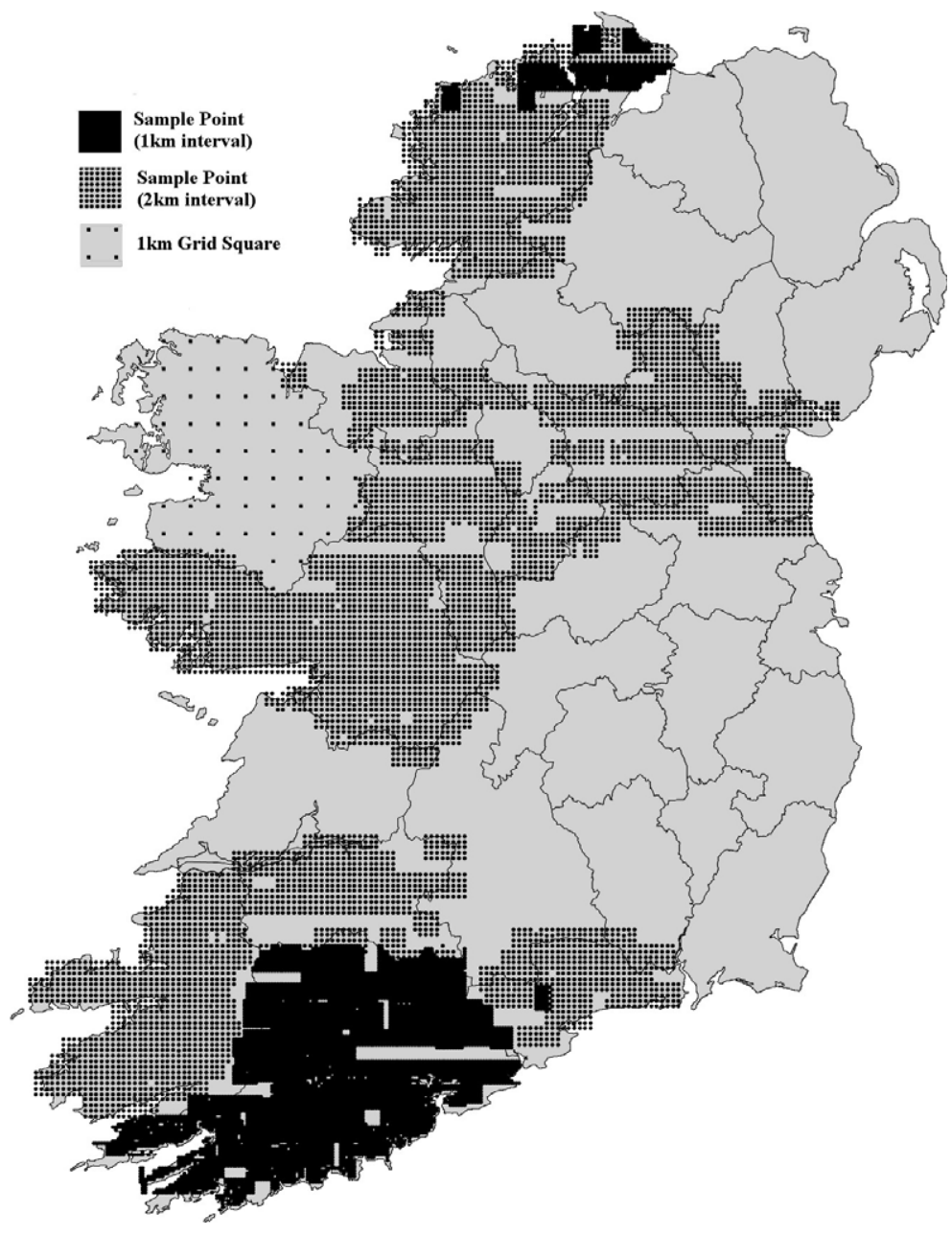

Fig. 4-Distribution of training data.

and resources were spent on the parent materials that occupied the largest area.

- Areas determined from a digital elevation model to be above $350 \mathrm{~m}$ were not generally sampled because we envisaged that these areas were less likely to be subject to afforestation.

\section{RESULTS}

The FIPS-IFS project is still in progress: thus, for demonstration purposes, we present some preliminary results, including the percentage of classified land area occupied by the different land-cover thematic classes and the habitat composition of field data for County Mayo. The contribution that these data sets can make to the assessment of biodiversity in Ireland will be outlined in the discussion.

\section{TRAINING DATA COLLECTED}

In Mayo, 59 grid squares were mapped; an illustrative example is given in Fig. 2. Fig. 3, which shows a training data point from County Donegal, illustrates the sampling approach used in Cork and Donegal. To date, 15,663 training points have been classified. The distribution of training data at the time of writing is illustrated in Fig. 4. By July 2002, enough training data will be generated to produce thematic maps of land cover throughout the Republic of Ireland.

\section{SUPERVISED CLASSIFICATION OF SATELLITE IMAGERY}

At the time of writing, the supervised classification of the Landsat TM imagery has produced three thematic maps of land cover for counties Mayo, Cork and Donegal. The thematic maps illustrate the distribution of the land-cover classes: dry grassland; wet grassland; bog and heath; rock complex; exposed peat; mature plantation and woodland; scrub or unclosed plantation and woodland; built land; and water. The habitat make-up of the thematic classes is outlined in Table 4. Fig. 5 illustrates an example from County Mayo. The percentage of classified land area occupied by the different thematic classes in Mayo is outlined in Table 5. By July 2002, we envisaged that thematic maps of land cover will be available for each county in the Republic of Ireland.

\section{FIELD SURVEYS CONDUCTED}

At the time of writing, we have conducted site visits in seven counties: Mayo (554), Cork (195), Donegal (178), Roscommon (162), Waterford (54), Wexford (49) and Limerick (52). Table 3 shows the type of data recorded. The distribution of field data at the time of writing is illustrated in Fig. 6. The habitat composition of the field sites visited in County Mayo is given in Table 6. By July 2002, we will have completed enough field surveys to produce accuracy assessments for each of the thematic maps of land cover.

\section{DISCUSSION}

The contributions that the land-cover data sets from FIPS-IFS can make to the assessment of biodiversity are discussed here in relation to Irish data sources and the biodiversity framework suggested by UNEP.

\section{HABITAT BIODIVERSITY AND EXISTING IRISH DATA}

Hickie et al. (1999) report a paucity of baseline data with which to assess land-use change, habitat change and species trends in Ireland. They cite some important exceptions: the EC CORINE land-cover project (O'Sullivan 1994), and local, regional and national surveys by Dúchas of certain 
species and habitat types, including peatlands, woodlands and grasslands. The National Heritage Inventory of the 1970s identified and listed areas of scientific interest (ASIs) (Foras Forbartha 1981), and updated the list in the 1980s (Wildlife Service 1989). The National Parks and Wildlife Service (NPWS) revisited ASIs and other sites throughout the 1990s and produced a list of proposed natural heritage areas (pNHAs). The pNHA sites have served as the source inventory for the list of proposed candidate special areas of conservation (pCSACs) that is being prepared in order to meet Ireland's obligations under the EU Habitats Directive. Other surveys worthy of mention here include Dúchas surveys of machair sites, the badger and habitat survey of Ireland (Smal 1995) and the survey of lowland grasslands in Ireland (O'Sullivan 1982).

However, the contribution that these surveys can make to the assessment of biodiversity and particularly habitat change in Ireland is limited by a number of factors. Many of these surveys concentrate on specific habitat types, for example grasslands, peatlands, machair and woodland, thereby ignoring others. With the exception of the badger and habitat survey, the lowland grassland survey and the CORINE project, habitat surveys are on sites of high conservation status and ignore the wider countryside, where biodiversity is still an issue. The surveys produce data at different spatial scales (CORINE, 25ha; lowland grassland survey, $\left.4 \mathrm{~m}^{2}\right)$. Classification schemes vary from broad and

Table 4-Habitat make-up of thematic classes, derived from field observations.

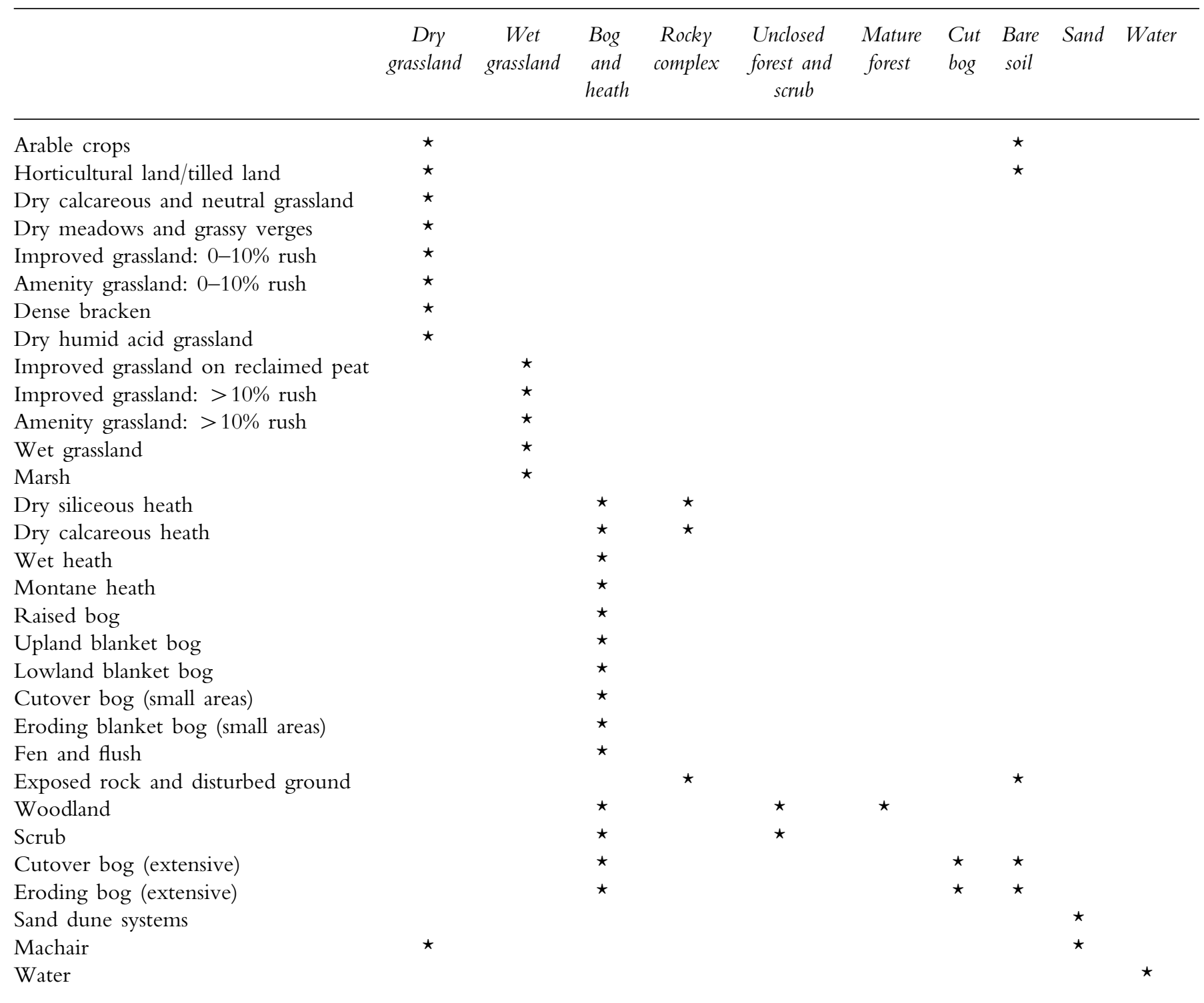

Habitat definintions from Fossitt (2000). 


\section{Thematic Class}

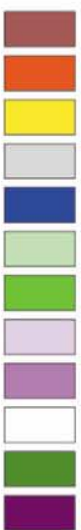

Bare Soil

Built Land

Sand

Rocky Complex

Water

Dry Grassland

Wet Grassland

Cut Bog

Bog\&Heath

Unclassified

Mature Forest

Forest(U) \& Scrub
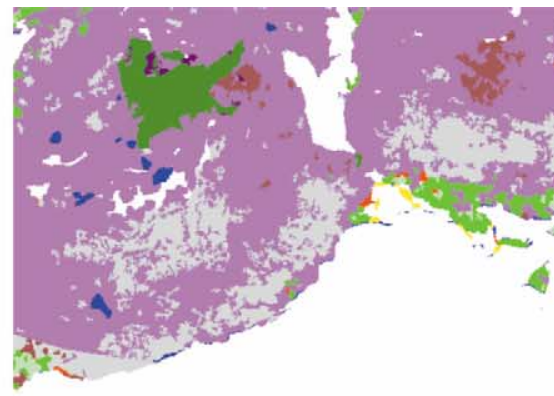
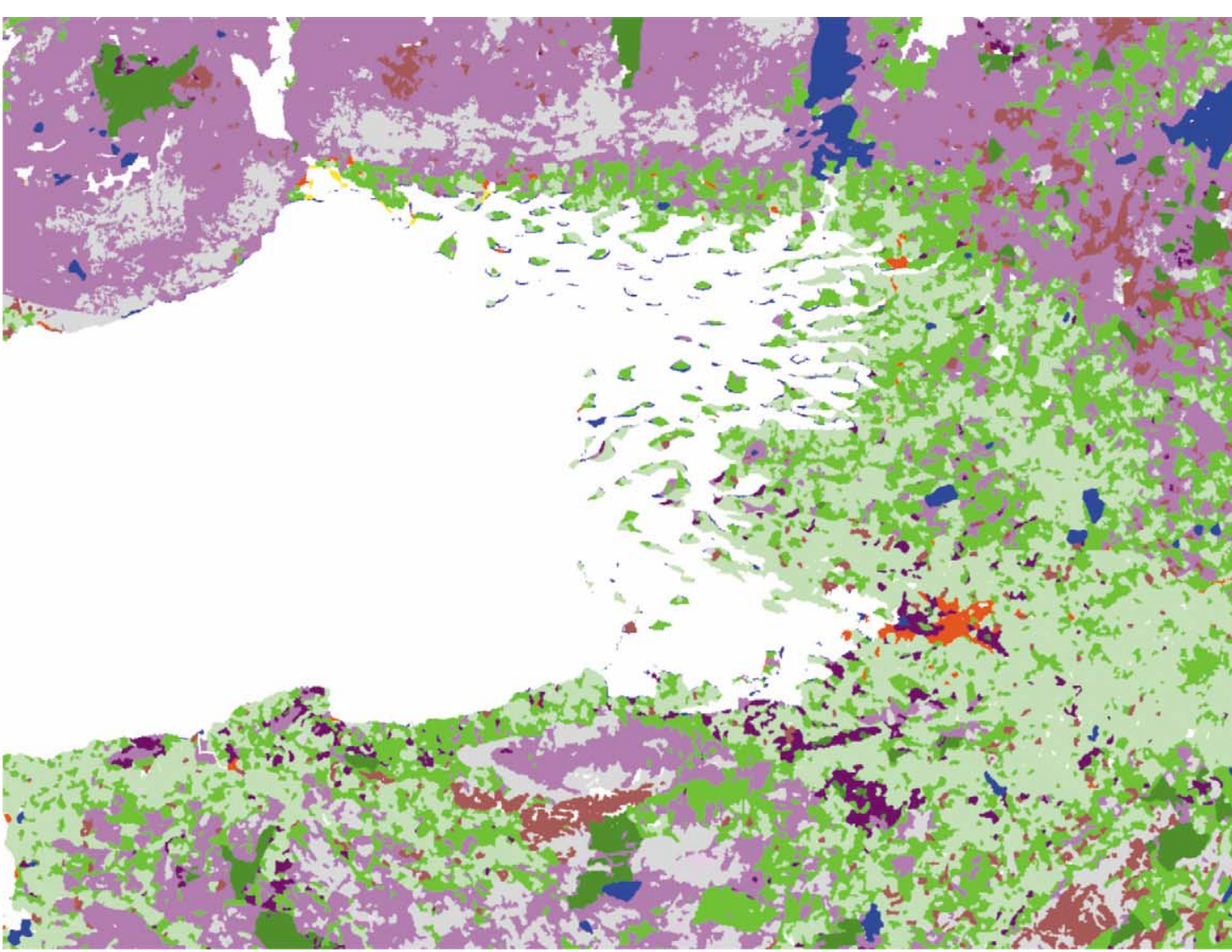

Fig. 5-Sample from thematic map of land cover centred around Clew Bay, Co. Mayo.

often heterogeneous land-cover classes, as in CORINE (O'Sullivan 1994), to more detailed species lists and academic phytosociological classifications, such as those adopted in the lowland grassland survey (O’Sullivan 1982).

Because the surveys span decades (the 1960s to the 1990s), their different spatial and classification resolutions cannot be used when assessing biodiversity or habitat change nationally in a base year. With the exception of CORINE and some informal use of aerial photography, the use of GIS, GPS and remote sensing in these surveys is limited. The information from these surveys is annotated on maps of varying scales, ranging from 1:10,560 (pNHAs and pSAC surveys) to 1:126,720 (lowland grassland surveys). Owing to practical limitations, sites annotated on such scale maps can be difficult to revisit because accuracy is a problem, particularly where little geographical context is evident, for example field boundaries, road junctions and confluences of streams and rivers.

In this context, the FIPS-IFS data sets are potentially useful in the assessment of biodiversity and habitat change in Ireland. The data are derived from contemporaneous imagery and field surveys (from 1995 to the present). The data-collection exercises do not concentrate on specific habitat

types of high conservation status or ignore the wider countryside. The process of mapping land cover is driven by data collected by one interpreter, eliminating error caused by differences in interpretation and ensuring a consistent countrywide data set. The surveys produce data from imagery with resolutions ranging from $1 \mathrm{~m}$ to $30 \mathrm{~m}$, with positional accuracy ranging from $0.5 \mathrm{~cm}$ to $40 \mathrm{~m}$ (RMS) and with different classification systems. The information can therefore be used in

\section{Table 5-Percentage area of terrestrial land occupied by different thematic classes in County Mayo.}

Thematic class name

Bog/heath and cut bog

Dry grassland

Wet grassland

Sand

Bare soil

Forest (unclosed) and scrub

Rocky complexes

Mature forestry

Built land
Area (\%)

37.9

27.7

20.5

0.1

4.7

1.8

3.4

3.4

0.5 
considering biodiversity at different classification and spatial scales. The data sets are registered to the national grid, and each site can therefore be revisited to determine positional accuracy.

\section{BIODIVERSITY FRAMEWORK}

The report published by the United Nations Environment Programme on the development of indicators of biological diversity (UNEP 2000) identifies a core set of state biodiversity indicators relating to ecosystem quantity and quality in certain thematic areas, including mountain biodiversity and agrobiodiversity. In Ireland we can take these to mean the semi-natural and agricultural landscape. The types of data sets and methods suggested as appropriate for quantifying and qualifying these indicators are outlined in Table 1. GIS and remote sensing with ground truthing are listed as suitable methodologies for measuring ecosystem quantity. Moreover, GIS with remote sensing and ground truthing are listed as fitting methodologies for measuring ecosystem quality through monitoring of processes such as habitat fragmentation, habitat conversion and erosion. Recording the change in abundance and distribution of a core set of species through surveys and monitoring programmes is also mentioned as an apt approach to measuring ecosystem quality.

While mapping land cover under the FIPS-IFS project, researchers gather information on the thematic areas suggested by UNEP. GIS and remote sensing, along with ground truthing (the tools for data capture suggested by UNEP), are central to the FIPS-IFS methodology. The field data can also be used to measure ecosystem quality, as outlined by UNEP, particularly by recording the abundance and distribution of a core set of species through surveys and monitoring programmes (Table 1).

The potential contribution of training data to the assessment of biodiversity

The minimum mapping unit is $0.78 \mathrm{ha}$, as described earlier, and the training data follow a land-cover classification that is aligned to a national standard (Fossitt 2000). The systematic way in which training data are collected and the sampling intensity allow for the quantification of land-cover classes on a regional scale to the baseline year 1995. Moreover, as the positional accuracy of the imagery is $5-10 \mathrm{~m}$ (RMS), sample sites can be revisited either remotely or in the field. These specifications determine the type of change and scale that the training data permit in the assessment of biodiversity.

The approach described above facilitates the monitoring of changes from one land-cover class to another over time. More subtle changes-

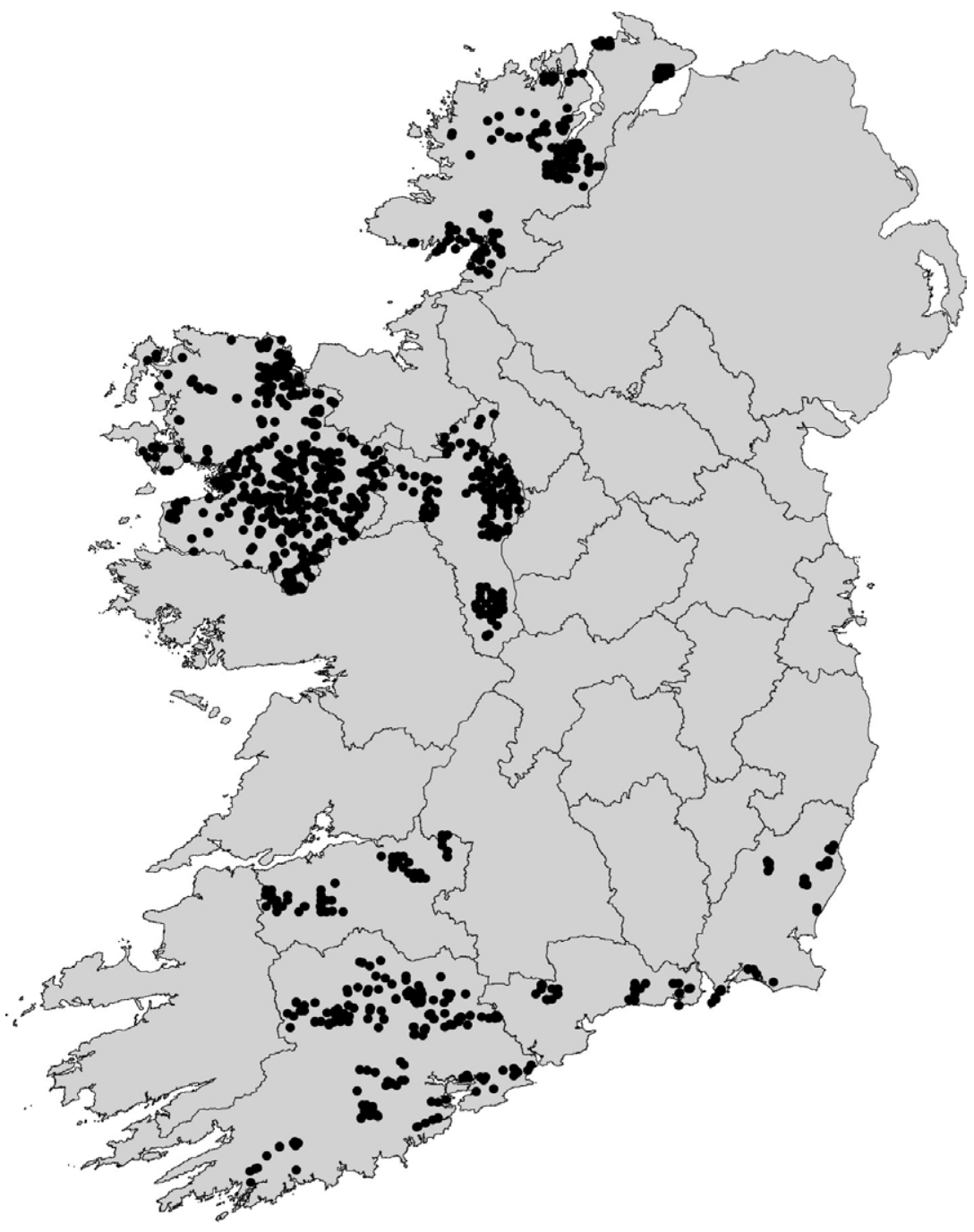

Fig. 6-Distribution of field survey sites.

indicative of habitat fragmentation, conversion and erosion, which often result from changes in agricultural management regimes-can be identified, for example scrub invasion or clearance, rush invasion or clearance, changes in turbary practice, heath reclamation, peatland erosion, etc. Again, the systematic way in which training data were collected permits the quantification of these types of changes to the baseline year 1995.

The potential contribution of thematic maps of land cover to the assessment of biodiversity

Given the large minimum mapping unit (1-5ha), the thematic maps of land cover monitor only changes of large areal extent ( $>1-5 \mathrm{ha}$ ) from one thematic class to another over time. Moreover, because the thematic classes are coarse, habitat fragmentation and conversion as indicators of ecosystem quality can be monitored only through a restricted set of abrupt changes in land use, for 
example urbanisation, afforestation, reclamation and peatland extraction. The thematic maps of land cover, unlike the training data, cannot be used to describe or quantify more subtle changes in vegetation. The methodology adopted in generating the thematic maps within FIPS-IFS permits changes in biodiversity indicators to be quantified on a regional scale to the baseline year 1995.

The potential contribution of field data to the assessment of biodiversity

The land-cover classification used for field surveys, like that used for training data, is based on the Guide to habitats in Ireland (Fossitt 2000), and more

Table 6-Habitat composition of field sample in County Mayo.

\begin{tabular}{lc}
\hline Cover one & $\begin{array}{c}\text { Field sites } \\
\text { visited }(n)\end{array}$ \\
\hline Active quarries & 2 \\
Arable crops & 1 \\
Bare ground or spoil & 2 \\
Bog woodland & 1 \\
Broadleaved woodland & 1 \\
Built land & 1 \\
Coarse grassland & 1 \\
Conifer woodland & 11 \\
Cutover bog & 4 \\
Complex grass, wet heath and rock & 1 \\
Complex wet heath and rock & 1 \\
Dense bracken & 1 \\
Exposed sand, gravel or till & 5 \\
Exposed scree or loose rock & 1 \\
Fen & 3 \\
Flush and spring & 3 \\
Improved grassland on peat & 32 \\
Improved grassland & 295 \\
Lowland blanket bog & 12 \\
Semi-natural dry grassland & 16 \\
Semi-natural wet grassland & 94 \\
Marsh & 9 \\
Mixed broadleaved conifer woodland & 1 \\
Native scrub & 10 \\
Oak birch holly woodland & 1 \\
Raised bog & 4 \\
Reedbed & 2 \\
Upland blanket bog & 6 \\
Wet heath & 28 \\
Total & 549 \\
\hline & \\
\hline
\end{tabular}

detailed ecological and species information is also recorded. As mentioned earlier, the sampling strategy used for field surveys biased site visits towards lower-elevation grassland areas and therefore limited the potential use of the resulting data in quantifying aspects of biodiversity. These specifications determine the type of change and the scale to which the field data apply in the assessment of biodiversity.

The approach described above facilitates the monitoring of changes in ecosystem quality over time. As is the case for training data, this approach allows the identification of subtle changes (e.g. scrub invasion or clearance, rush invasion or clearance, changes in turbary practice, heath reclamation, peatland erosion, etc.) that indicate habitat fragmentation, conversion and erosion, often resulting from changes in agricultural management regimes. The UNEP report recommends recording the change in abundance and distribution of a core set of species through surveys and monitoring programmes as a suitable means of measuring ecosystem quality (UNEP 2000). In this context, the field data can be used to identify changes in species dominance.

The high positional accuracy and level of detail in the field data allow for description and monitoring of changes in ecosystem quality at the local and field scale from the baseline years 1998-2002. As already stated, owing to a bias in the field sampling strategy towards low-lying grasslands, the field data are best suited to qualifying and not quantifying these types of changes.

\section{CONCLUSION}

The FIPS-IFS land-cover data sets relate to the wider countryside and provide information on a range of terrestrial habitats for which heretofore few data existed. The data can be used to describe and measure biodiversity indicators identified by UNEP, such as habitat fragmentation, habitat conversion and erosion. It has been demonstrated that these data sets can be used to monitor ecosystem quantity and quality at different classifications, spatial resolutions and scales. In line with best practice, current technology is being used for data collection (remote sensing and GPS) and data storage (GIS) (UNEP 2000). The habitat and land-cover classifications, which form the core of the training and field data collection exercises, are aligned to a national standard (Fossitt 2000). This national standard will guide future habitat surveys, the results of which can then be used in conjunction with the FIPS-IFS data sets to assess changes in biodiversity in Ireland. 


\section{ACKNOWLEDGEMENTS}

We thank the Forest Service, Department of the Marine and Natural Resources, the National Development Programme (NDP) and the European Union, all of which contributed to the funding of this project.

\section{REFERENCES}

Baker, R.D., DeSteiguer, J.E., Grant, D.E. and Newton, M.J. 1979 Land-use/land-cover mapping from aerial photographs. Photogrammetric Engineering and Remote Sensing 45, 661-8

Bulfin, M. 1998 Forest soils classification and productivity, 27. Teagasc R \& D programme project portfolio 1998. Dublin. Teagasc.

Campbell, J.B. 1983 Mapping the land: aerial imagery for land use information. Resource Publications in Geography. Washington, DC. Association of American Geographers.

Campbell, J.B. 1996 Introduction to remote sensing. 2nd edn. London. Taylor and Francis.

Cooper, A. and Loftus, M. 1998 The application of multivariate land classification to vegetation survey in the Wicklow Mountains, Ireland. Plant Ecology 135, 229-41.

Coulter, B.S., Lee, J. and McDonald, E. 1996 The status of soil survey information both conventional and GIS. In C. Le Bas and M. Jamagne (eds), Soil databases to support sustainable development, 61-9. European Soil Bureau Research Report no. 2. EUR 16371 EN. European Commission Joint Research Centre. Luxembourg. Office for the Official Publications of the European Communities.

Cruickshank, J.C. and Cruickshank, M.M. 1977 A survey of neglected agricultural land in the Sperrin Mountains, Northern Ireland. Irish Geography 10, $36-44$.

Cruickshank, M.M. and Tomlinson, R.W. 1990 Peatland in Northern Ireland: inventory and prospect. Irish Geography 23, 17-30.

Cruickshank, M.M. and Tomlinson, R.W. 1996 Application of CORINE land cover methodology to the UK-some issues raised from Northern Ireland. Global Ecology and Biogeography Letters 5, $235-48$.

Department of Agriculture, Food and Forestry 1996 Growing for the future-a strategic plan for the development of the forestry sector in Ireland. Dublin. Stationery Office.

Foras Forbartha 1981 Areas of scientific interest in Ireland. Dublin. An Foras Forbartha.

Fossitt, J.A. 2000 A guide to habitats in Ireland. Kilkenny, Ireland. The Heritage Council.

Howard, J.A. 1970 Aerial photo ecology. London. Faber and Faber.

Loftus, M. 1994 The ecology and management of upland vegetation in the Wicklow Mountains. Unpublished $\mathrm{PhD}$ thesis, University of Ulster, Coleraine.

Loftus, M., Butler, C., McMillan, G. and Boyle, A. 1998 Illustrating distribution patterns of hedgerow classes and broad-leaved woodlands in the planned and ancient landscapes of Hampshire, using GIS. In M.A. Atherden and R.A. Butlin (eds), Woodland in the landscape: past and future perspectives, 202-3. Leeds. Leeds University Press.

McNeely, J.A. 1988 Economics and biological diversity - developing and using economic incentives to conserve biological resources. Gland, Switerland. IUCN.

O'Sullivan, A.M. 1982 The lowland grasslands of Ireland. In J. White (ed.), Studies on Irish vegetation, 131-42. Dublin. Royal Dublin Society.

O'Sullivan, G. 1994 CORINE land cover project [Ireland]. Report produced for the Council of the European Communities, Directorates-General XI (Environment) and XIV (Regional policy). Dublin. Ordnance Survey of Ireland; Belfast. Ordnance Survey of Northern Ireland.

Smal, C. 1995 The badger and habitat survey of Ireland. Dublin. Stationery Office.

Hickie, D., Smyth, E., Bohnsack, U., Scott, S. and Baldock, D. 1999 Impact of agricultural schemes and payments on aspects of Ireland's heritage. Kilkenny, Ireland. The Heritage Council.

Tomlinson, R.W. 1984 Mapping peatland vegetation from readily available air photographs: a field test from Northern Ireland. Irish Geography 17, $65-83$.

UNEP [United Nations Environment Programme] 2000 Convention on Biological Diversity. Document UNEP/CBD/SBSTTA/5/12: Development of indicators of biological diversity. Proceedings of the Fifth Meeting of the Subsidiary Body on Scientific, Technical and Technological Advice, 31 Jan.-4 Feb. 2000, Montreal, Quebec, Canada. 13pp.

Wildlife Service 1989 Index to areas of scientific interest. Unpublished report to the National Parks and Wildlife Service, Office of Public Works, Dublin. 